\title{
Psychosocial risks: acting upon the organisation by ergonomic intervention
}

\author{
Johann Petit ${ }^{\mathrm{a}}$, Bernard Dugué ${ }^{\mathrm{a}}$ \\ ${ }^{a}$ Department Of Ergonomics, ENSC, Bordeaux Institute of Technology, 146 rue Léo-Saignat, 33076 Bordeaux \\ Cedex-France, johann.petit@ensc.fr
}

\begin{abstract}
In this paper we discuss the possibilities of acting on psychosocial risk (PSR) factors by modifying the way in which an organisation operates. On the basis of an ergonomic intervention in an insurance company, we were able to show that the health problems observed by the operators were mainly the result of their inability to produce work of quality. Next, our analyses revealed the links between poor perceived quality, production difficulties and the rigidity of the organisational structure. After setting up working groups to deal with production difficulties, we were able to identify and test an organisational form that was better adapted to managing day-to-day production constraints and which was ultimately better able to be attentive to individual difficulties which had given rise, in the long term, to intrapsychic conflicts.
\end{abstract}

Keywords: organisational design, PSR, quality of work.

\section{Introduction}

The work described in this paper is part of a research study into PSR and in particular the possibilities of action in this area. Over the last 40 years in ergonomics, the description of terms used to deal with variability has improved considerably. Adapting ways of working to cope with variability was first described as a requirement for productive efficiency (Laville, Teiger \& Duraffourg, 1972; Daniellou, Laville, \& Teiger, 1982). However, this ability to deal with situational variations is not purely reactive: it is based on, and feeds into the perceptive exploration of the environment by the operator (Berthoz, 1999). The world does not exist independently of the subject (Merleau-Ponty, 1990; Varela, 1988). By describing the interaction between the experience of the operator, the information he gleans from the situation, and the action that he will put into practice in this way, we can introduce the notion of a "sensitive relationship to work" (Böhle \& Milkau, 1998, Davezies, 1995). The description of this sensitive relationship to work can be enriched still further when one considers relationships that the operator develops with other humans through his relationship with the subject of his work. The operator gradually realises that, depending on the way in which he car- ries out his work, there can be positive or negative consequences for other humans, colleagues, clients, patients etc. (Teiger, Cloutier, \& David, 2005; Davezies, 2006). Work must always be taken into consideration, as Clot (1999) highlighted. Leontiev (1984) points out that human activity is "pulled by goals" and "pushed by motives". In the first stages of a work activity, we can imagine that the operator's motives are mainly economic, and that his goals are determined by the way in which the work is organised. However, when the subject discovers that relationships can be formed with others as he carryies out work activities, this rather changes things: based on his personal motives, his values, his beliefs, the subject will set himself new goals in his work, which correspond to the idea that he has created of "a job well done", for example the fact of facilitating work for a colleague or improving service to the client (Davezies, 2006). The sensitive relationship with the object is in fact a relationship with a third party, and is the basis for creativity (Rabardel \& Pastré, 2005). The problem, as far as the health of the operators is concerned, is not the existence of a contradiction in goals, which is a normal component of company operations. Rather, it is the fact that not only are these conflicting goals not recognised, but nor are they even discussed. If there is no debate about work, 
about its peculiarities, its variabilities, then there is no searching for common goals, between those of the operators and those of the organisation. It will become difficult even impossible for the operator to manage these variations properly, ("activity prevented", Clot, 2006), and as these situations start to occur more and more frequently they will start to cause disharmony with the operator's motives. He may often have to manage paradoxical injunctions (Watzlawick, Weakland, \& Fisch, 1975). If, in addition, the organisation sets the operators to compete one against the other, then these contradictions will probably not be able to be shared with colleagues, and each individual will find himself isolated and coping with the situation alone. The intrapsychic conflicts that develop will then reflect the social debates that are not taking place.

\section{Background}

To clarify these theoretical aspects, we focus on the case of an ergonomic intervention in an insurance company. The initial request was for possible assistance in dealing with PSR. In the space of only 10 years, the company had experienced several major changes: a merger of three regional establishments, a departmental reorganisation with specialisation being allocated according to geographic site, the creation of a telephone service platform and the introduction of a policy of electronic Information and Documentation management with the aim of dematerialising all documents. During this period of successive upheavals, the company lost about $10 \%$ of its staff, including several from management positions. Today, it has 400 employees. This was the context when several alarm bells went off and came to the attention of the elected representatives of the Health and Safety Works committee (CHSCT) and the company doctor who became aware of a growing "melancholy" on the part of the employees: sick leave, individual complaints, difficulties in carrying out the work required, lack of training, crying in the workplace. In addition, the management noted a deterioration in production indicators (considerable delays), in the quality of work (time taken to deal with cases, complaints, clients having difficulty making contact) and in staff management (absenteeism).

\section{Methodology}

We therefore based our thinking on the idea developed earlier, that psychosocial tensions are played out precisely in the work carried out by each individual, and that it is there that the resources can be found to overcome these difficulties, to discuss them and once again establish ties with colleagues. Rather than launch a large-scale operation throughout the entire company, we suggested selecting a few departments where the process could be introduced and "tested" before replicating it in a wider context. The intervention was therefore structured on several levels.

First, a steering group was formed, made up of the executive board and representatives from the CHSCT. In these first stages we had to reach agreement on the problem to be dealt with, the procedure to follow and to approve the departments in which the study was to be carried out. Seven units were chosen where problems had been identified, but at our request there was also one department that was reputed to be "problem free". The staff in these departments represented about $40 \%$ of the total workforce. Several days were then spent in these departments by the scientists observing the work before moving on to a phase of individual interviews. Finally, a working group was formed in each department to validate the data collected during the observations and interviews, to gather further data and discuss possible courses of action. These working groups included employees from administration and others who were supervisors. Next, a managers group was created to discuss the work specifically done by the supervisory staff. In all, we carried out 71 interviews with the employees and the managers of the various departments, five days of work observation, eight working group meetings, seven interviews with the board, three with the company doctor, and four with the CHSCT representatives.

\section{Results}

After analysing the content of the interviews, we were able to categorise the words of the operators and thus assess the links formed by the employees between their health, the quality of the work carried out, the production processes and the organisational structure. These categories were created on the basis of terms used during the interviews and they were vali- 
dated by the operators concerned (management and technicians). More precisely:

- $74 \%(53 / 71)$ linked their health and the quality of their work;

- $62 \%(44 / 71)$, linked the quality of their work and production processes;

- $66 \%$, linked production processes and the organisational structure;

- Finally, 39 employees out of 71 (55\%) established links between all 4 categories.

In addition, the interviews provided us with some concrete examples of productive constraints and the "organisational complexities" applied to resolve them, some precise consequences for the quality of work, and finally, expressions related to what the employees felt vis-à-vis their health. Our diagnosis helped identify several "stumbling blocks", relating to a lack of quality in the work carried out, organisational rigidity, a necessary reliance on processes, under-use of employees' know-how, a deterioration in group work and major difficulties surrounding the work done by the managers. All these points highlighted the difficulties experienced by both managers and employees in coping with the different changes that had taken place and with their inability to change the existing organisational structure. The rest of the study consisted in dealing with the everyday problems (calls not dealt with, delays in handling cases, errors, etc.) by proposing solutions at different levels (transfer tasks, modify procedures, training session, etc.) and pointing out organisational failures which had until then prevented both managers and employees from resolving them.

\section{Discussion}

Given the results described above, we observe that in the context of the major change that this company was undergoing, operators were constantly adapting but always within limits dictated by their health and the efficiency of production. It seems to us that if the resilience of the organisation had been built up beforehand (Hollnagel, Woods, \& Leveson, 2006), for example by improving its ability to anticipate, early detection, and responding appropriately if the system operates in a way that diverges from the reference conditions, in order to minimize their effects on its dynamic stability, then this would have prevented the negative consequences described above. The organisational structure should, above all else, have ensured production reliability and, in our opinion, 3 production reliability and, in our opinion, 3 stages of regulation seem to have been forgotten:

Identifying a problem

- This is based on exchanges between colleagues;

- They talk, they are listened to and they discuss together the reality of the problem, its scale and its consequences;

- At these discussions about work different points of view should emerge on the quality of work produced and the different ways of producing it.

- Send the problem up the chain of command

- Inform the hierarchy of the difficulties identified collectively, perhaps with some suggestions for resolving them;

- Wait for the hierarchy to deal with the problem in one way or another.

Dealing with the problem

- Be able to categorise problems according to their consequences and also in terms of the means to be employed to resolve them;

- Be able to deal with a low priority matter at the lowest level of the hierarchy;

- Be able to send up the chain of command any cases that require more complex decision-making circuits.

The goal is to ensure production reliability by eliminating everything that hampers this and prevents employees producing results that they "judge" to be of good quality. This quality judgement cannot depend only on purely economic criteria, It must also take other aspects into account which may be underestimated by management: the social, financial, or psychological distress of a client, an accumulation of case files, a colleague's absence, the particular technical aspects of a case under consideration, the time allocated to dealing with the most complicated cases, etc. To do this, the appropriate people have to be included in the regulation loop, in other words the operators who are closest to production. By dealing with difficulties at work in this way, as well as ensuring the reliability of production, each employee has the space to express what it is that causes them a problem. In this way a collective dimension can be given to an individual problem (Sen, 2008) which might otherwise very quickly result in the isolation of the individual, who has no other means of resolving his difficulties (not by colleagues, nor by the hierarchy). 
The implication is that there is a fundamental question to be dealt with in terms of the functioning of the organisation, i.e. the distribution of areas of decisionmaking along the chain of command. In other words, we should consider what should be dealt with at each level of the hierarchy, from the technical operator to the board of directors, in order to make the work more rewarding for everyone, to develop autonomy and responsibility, and not clog up the hierarchy with matters that could very well be dealt with at a lower level, thus facilitating greater reactivity. This means instigating a way of operating that is based on delegating power to those who can use it properly, developing organisational confidence, somehow inventing a more "just" capacity for action and decision-making. This is a question of efficiency, of everyone taking responsibility, and hence, ultimately, of organisational reliability. In our opinion, the notion of subsidiarity can help define the shape of such an organisation. In the company in question, the need for consistency in the responses given to clients and ensuring the reliability of the processes involved was mentioned as justification of the high degree of centralisation of management decisions, including those that concerned everyday operations. Certainly, some decisions would benefit from being taken centrally, but others would certainly not. Yet neither was there a list which defined from the outset those decisions that could be taken at each of the different levels of the hierarchy. To be efficient, it was necessary to constantly adapt the level of decision-making to the problem to be dealt with and in that precise context, according to the knowledge available to everyone concerned. This supposes an organisation that is sensitive to the minutiae of work events and which can continually adjust the levels at which matters are dealt with, and use levers located at different levels of the hierarchy (Hasle \& Møller, 2007). However, for it to be possible to transfer from one decision-making level to another, the organisation and all the people in it must be prepared for it.

The principle of subsidiarity is a very old notion of which we find the beginnings in Aristotle. It was in the $17^{\text {th }}$ century that Althusius constructed a theory by which political relations between individuals and communities could be understood and organised, with a view to avoiding any concentration of powers and giving the "inferior" communities autonomy in accordance with the idea of "distribution of competence". The principle of subsidiarity became popularised when it was introduced into the Maastricht Treaty (Cameron \& Ndhlovu, 2001; Colombo, 2008), and in France, it formed the basis of the newly established relationships between regional authorities and the State in the context of decentralisation. Clearly, we are not comparing our situation with this political application of the principle of subsidiarity, however we want to point out the relevance of this notion when applied to the sphere of organisational design (Melé, 2005). Here indeed we find a thought in the same vein as Thomas Aquinas, Pope Pius XI's encyclical, "Quadragesimo Anno" (1931) and that of Pope John XXIII "Mater et Magistra" (1961), and outlined by advocates of social Catholicism who were critical of both Taylor's concepts and also the school of human relations in matters of company organisation and management. One definition (Pradines, 2004) highlights 3 main principles:

- $\quad$ the higher grades will refrain from carrying out any task that the lower grades can carry out for themselves (principle of competence);

- the higher grades have a duty to discharge those tasks that the lower grades cannot carry out (principle of help);

- $\quad$ the lower grades will refrain from transferring certain tasks that fall specifically to them (principle of replacement).

Subsidiarity is therefore seen as a model for cooperation and solidarity, for building an organisational structure with interlocking parts, where each level retains its ability to act and its autonomy, where each individual has his own "piece of sovereignty", just as Proudhon wanted, as he too was a defender of the principle subsidiarity.

We do not consider the principle of subsidiarity as a template to be applied to organisational design, but rather as an aid to reflection on what a "sustainable" company might be. This way of perceiving relations within an organisation (company, administration, institution) can help us formulate a company structure and functioning which is not only effective but also respects individuals and their health. The concept of applying subsidiarity to the organisation could give us reason to revisit a certain number of other concepts that are used to explain the links between work activity and health: autonomy, the power to act, latitude in decision-making, organisational dependence, room for manoeuvre, regulations. It seems to us that by asking the question, "Why have something dealt with at a given level in the hierarchy when it can quite easily be dealt with at the lower level?", the idea of subsidiarity enables us to consider how these different concepts are put into operation and are im- 
plemented. It is not solely a question of management, but primarily a problem of organisational spaces in which employees will be able to exert their autonomy.

\section{References}

[1] Böhle, F., \& Milkau, B. (1998). De la manivelle à l'écran. L'évolution de l'expérience sensible des ouvriers lors des changements technologiques. Paris : Éditions Eyrolles.

[2] Cameron, J., \& Ndhlovu, T.P. (2001). The comparative economics of EU 'subsidiarity': lessons from development/regional economic debates. International Journal of Urban and Regional Research, 25, 2: 327-345.

[3] Clot, Y. (1999). La fonction psychologique du travail. Paris : PUF.

[4] Clot, Y. (2006). Action et connaissance en clinique de l'activité. Activités, 1, 1, 23-33.

[5] Colombo, A. (2008). The "Lombardy Model": Subsidiarity-informed Regional Governance. Social Policy \& Administration, 42, 2: 177-196.

[6] Daniellou, F., Laville, A., \& Teiger, C. (1982). Fiction et réalité du travail ouvrier. $\mathrm{La} \mathrm{Docu-}$ mentation française, les Cahiers français, 209, le travail ouvrier, 39-45.

[7] Davezies, P. (1995). Position du médecin du travail face aux dimensions cognitive, psychiques et relationnelles du travail. Archives des Maladies Professionnelles, 56, 4, 294-306.

[8] Davezies, P. (2006). Une affaire personnelle?. In L. Théry $(\mathrm{s} / \mathrm{d})$, Le travail intenable. Paris, Editions La Découverte, (pp. 138-168).

[9] Hasle, P., \& Møller, N. (2007). From Conflict to Shared Development: Social Capital in a Tayloristic Environment. Economic and Industrial Democracy, 28, 3: 401-429.
[10] Hollnagel, E., Woods, D., \& Leveson N. (2006). Resilience Engineering: Concepts and Precepts. Ashgate Publishing Ltd, Aldershot, UK.

[11] Laville A., Teiger C., \& Duraffourg J. (1972). Conséquences du travail répétitif sous cadence sur la santé des travailleurs et les accidents. Rapport final, no 29, Collection du Laboratoire de Physiologie du Travail et d'Ergonomie du Conservatoire National des Arts et Métiers, Paris, $385 \mathrm{p}$.

[12] Melé, M. (2005). Exploring the Principle of Subsidiarity in Organisational Forms. Journal of Business Ethics, 60: 293-305.

[13] Merleau-Ponty, M. (1990). Phénoménologie de la perception. Paris : Éditions Gallimard. (Edition originale, 1945, « Bibliothèque des Idées »).

[14] Pradines, P. (2004). Management : la subsidiarité, organisation de l'entreprise et enseignement de l'Eglise. http://biblio.domuni.org/articlesphilo/subsidiarit e/

[15] Rabardel, P., \& Pastré, P. (2005). Modèles du sujet pour la conception. Toulouse : Octarès.

[16] Sen, A. (2008). The Idea of Justice. Journal of Human Development, 9, 3, 331-342.

[17] Teiger, C., Cloutier, E., \& David, H. (2005). Les activités de soins à domicile : soigner et prendre soin. In M. Cerf et P. Falzon (Eds.), Situations de service: travailler dans l'interaction (pp. 179-204). Paris : PUF.

[18] Varela, J.F. (1988). Connaître les sciences cognitives : tendances et perspectives. Paris : Éditions du Seuil.

[19] Watzlawick P., Weakland J.H., \& Fisch R. (1975). Changements, paradoxes et psychothérapie. Paris : Éditions du Seuil. 